\title{
Unsung hero: Donald Darrow Matson's legacy in pediatric neurosurgery
}

\author{
Roberta Rehder, MD, Subash Lohani, MD, and Alan R. Cohen, MD \\ Department of Neurosurgery, Boston Children's Hospital, Harvard Medical School, Boston, Massachusetts
}

Donald Darrow Matson made seminal contributions to the field of pediatric neurosurgery. Born in 1913 in Fort Hamilton, New York, Matson was the youngest of four sons of an army colonel. He graduated from Cornell University and, years later, from Harvard Medical School. Matson selected Peter Bent Brigham Hospital for his neurosurgical training, which was interrupted during World War II. As a neurosurgeon, he worked close to the front lines under Brigadier General Elliot Cutler in Europe, earning a Bronze Star. Matson returned to Boston to become Franc Ingraham's fellow and partner. He was a masterful surgeon and, with Ingraham, published Neurosurgery of Infancy and Childhood in 1954, the first pediatric neurosurgery textbook in the world. Upon Ingraham's retirement, Matson became chairman of the department of neurosurgery at Boston Children's Hospital and Peter Bent Brigham. In 1968, he became the inaugural Franc D. Ingraham Professor of Neurological Surgery at Harvard Medical School. Among his neurosurgical accomplishments, Matson served as President of the Harvey Cushing Society, later known as the American Association of Neurological Surgeons. He was unable to preside at the 1969 meeting that marked the 100th anniversary of Cushing's birth, having contracted Creutzfeldt-Jakob disease. Matson died at the age of 55, surviving his mentor Ingraham by only 4 years.

http://thejns.org/doi/abs/10.3171/2015.4.PEDS156

KEY WORDS Donald Darrow Matson; pediatric neurosurgery; Boston Children's Hospital; Franc Ingraham; history; Creutzfeldt-Jakob disease

$\mathrm{D}$ ONALD Darrow Matson (1913-1969), whose life was cut short in its prime by catastrophic illness, made seminal contributions to the field of pediatric neurosurgery and is considered one of its founding fathers (Fig. 1). ${ }^{3}$ Matson was a remarkable man and a skillful neurosurgeon, yet he has not received the recognition he deserves for his pioneering work in pediatric neurosurgery. Here we discuss his extraordinary career and his role in introducing the modern era of neurosurgery in general, and pediatric neurosurgery in particular. Based on a review of the literature as well as interviews with his surviving friends, colleagues, and family, we recount some of his many scholarly contributions along with colorful vignettes from his personal life.

\section{Childhood and Early Achievements}

Matson was born on November 28, 1913, in Fort Hamilton, New York, the youngest of four sons. His father, Jo- seph Matson (1876-1956), was a colonel in the US Army Coast Artillery Corps, whose last tour of duty was in Hawaii. The family then settled near Pasadena, California, and Matson's father began working as a municipal engineer. ${ }^{3}$ By then his wife, Kathleen (1877-1946), was pregnant with her fourth child. Kathleen was one of three sisters and already had given birth to Joseph Jr., Francis, and Ned. She had hoped the fourth baby would be a girl, but that would not be the case. Donald Darrow Matson was born large, with a birth weight of 14 pounds. The day she delivered him, Kathleen remarked, "to think I could have had two perfectly good girls for that!" ${ }^{90}$ Matson considered himself an "Army brat" and lived in many parts of the United States during his infancy and childhood, with multiple interruptions in his schooling. When discussing the many struggles of residency training, he once recalled to Francis D. Moore (1913-2001), his longtime friend and surgical colleague, "Well, I was raised as an intern."72

ABBREVIATIONS BCH = Boston Children's Hospital; $\mathrm{CJD}=$ Creutzfeldt-Jakob disease; $\mathrm{ETO}=$ European Theater of Operations; $\mathrm{HMS}=$ Harvard Medical School; $\mathrm{PBBH}=$ Peter Bent Brigham Hospital.

SUBMITTED January 5, 2015. ACCEPTED April 15, 2015.

INCLUDE WHEN CITING Published online July 31, 2015; DOI: 10.3171/2015.4.PEDS156.

DISCLOSURE The authors report no conflict of interest concerning the materials or methods used in this study or the findings specified in this paper. 


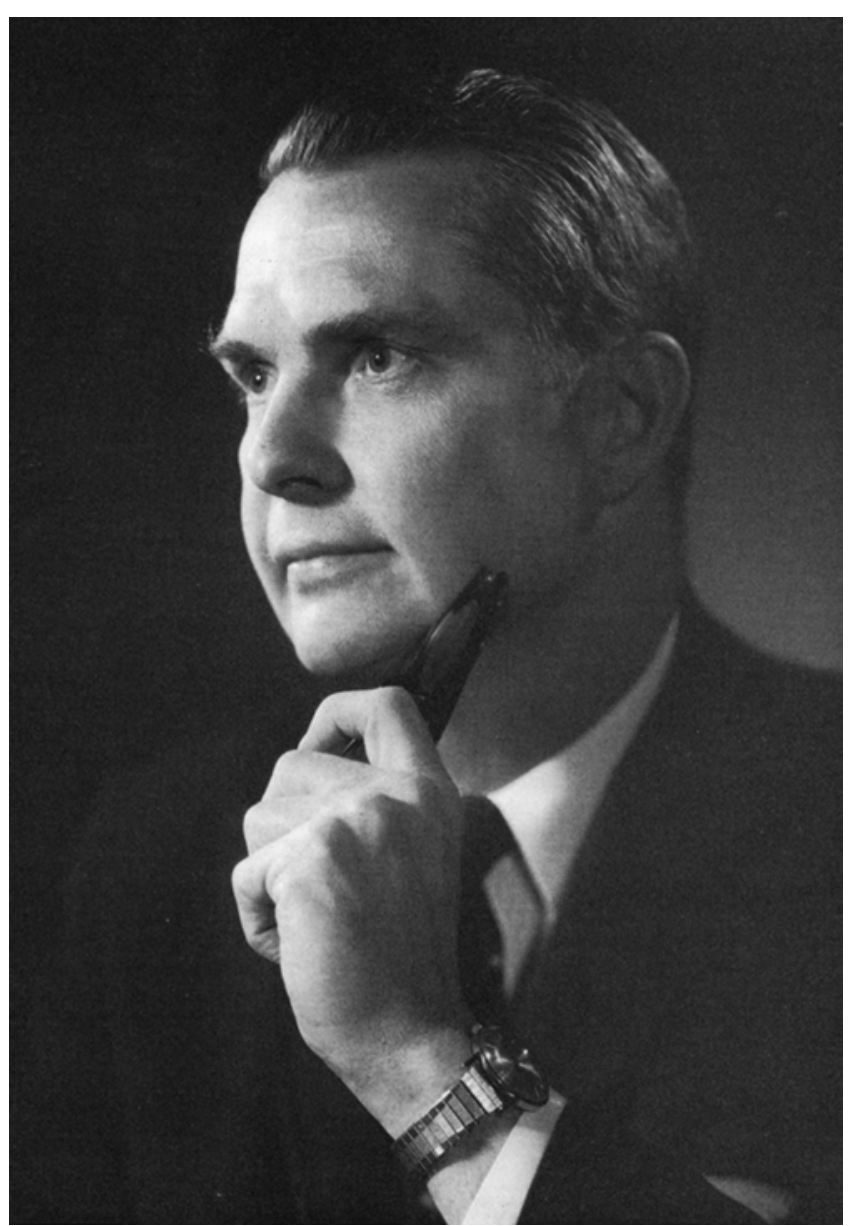

FIG. 1. Donald Darrow Matson, a founding father of pediatric neurosurgery. Copyright Boston Children's Hospital Archives, Boston, Massachusetts. Published with permission.

Matson was not only a brilliant student but also a great athlete. His favorite sports were swimming, tennis, and golf. He was an outstanding swimmer and, as a young man, won a race around Balboa Island in Southern California. Later, he competed for a place on the United States Olympic swimming team along with the legendary Johnny Weissmuller, one of the fastest swimmers of the early 20th century. ${ }^{3}$ Weissmuller was also an actor and is perhaps best remembered for his distinctive yell in his role as Tarzan in the movies. ${ }^{96}$

Matson's remarkable intellectual abilities were recognizable early on. He won a Telluride Foundation scholarship, which was established to support the education of gifted students. ${ }^{3}$ Sponsored by the great silver mine operator Lucien Lucius Nunn, the Telluride scholarship selected exceptional students to attend Deep Springs College near Death Valley. ${ }^{29}$ The Foundation believed that those students would become future leaders in a democratic society, if isolated from the distractions of cities and given an education that combined hard outdoor physical work and rigorous study. Nunn's endowment included a scholarship to Cornell, where there was a Telluride House. ${ }^{31}$ Matson entered the college at age 16 and went on to graduate with honors from Cornell in $1935 .{ }^{100}$ He repaid Nunn's gener- osity by teaching students and helping in the selection of candidates to attend Deep Springs.

In medical school, Matson was elected president of the Alpha Omega Alpha Society and a was a member of the Boylston Society. ${ }^{3}$ He published an article with John Rock (1890-1984), an obstetrician and gynecologist, on anovulatory menstruation and the diagnosis of infertility. ${ }^{85} \mathrm{Sub}$ sequently, Rock and his team would introduce the birth control pill in $1955 .^{79}$ As a fourth-year medical student, Matson presented a paper on pulmonary infection entitled, "Lung abscess," based on work he had done with Thomas Lanman, a thoracic surgeon at Boston Children's Hospital $(\mathrm{BCH}){ }^{58,72}$ Following Matson's graduation, the paper was published as a major review article in the New England Journal of Medicine..$^{58}$

Matson began his residency training on July 1,1939 . He chose to train at Peter Bent Brigham Hospital (PBBH) and $\mathrm{BCH}$, one of the most demanding programs in the country, under the supervision of Elliot Carr Cutler (1888-1947) and William Edwards Ladd (1880-1967). Cutler, a cardiac surgeon, was surgeon-in-chief at Brigham and became famous for the first successful valve surgery in the world. He served as Brigadier General in the US Army Medical Corps and was named Chief Consultant in Surgery in the European Theater of Operations (ETO) in World War II. ${ }^{86}$ Ladd, surgeon-in-chief at Children's, became known as the "father of pediatric surgery." 103 Before going to war, Matson managed to complete a classic paper with his mentor, Franc D. Ingraham (1898-1965), entitled "Subdural hematomas in infancy," published in the Journal of Pediatrics. ${ }^{4,44}$ As a resident, Matson was extremely hard working and motivated. His work ethic and unlimited energy paid off as he was often rewarded by being allowed to scrub on cases that would otherwise have been assigned to senior trainees. ${ }^{72}$

\section{World War II}

In the midst of his residency training, Matson and his classmate Eben Alexander Jr. (1913-1980) joined the US Army to serve in World War II. ${ }^{11}$ They were assigned to Walter Reed General Hospital in Washington, DC, and served there for 3 months, under Major Roy Glenwood Spurling (1894-1968), who organized the Army's neurosurgical service and assigned Matson to the ETO.,1,77 In Europe, Matson served under Brigadier General Cutler as a member of the Fourth Auxiliary Surgical Group. Matson already had a professional history with Cutler, who had been chosen to succeed Harvey Cushing (1869-1939) as Moseley Professor of Surgery at Harvard Medical School (HMS) and surgeon-in-chief at PBBH, in 1932.19,86,90

During the war, Matson headed a neurosurgical team responsible for the care of the wounded in the ETO, working closely behind the front lines. ${ }^{90} \mathrm{He}$ served in the Army from 1943 to 1946 and, during the last 2 years, was stationed in Czechoslovakia. ${ }^{91}$ Based on his wartime experience, Matson wrote and published monographs for the Surgeon General of the US Army on cranial and spinal injuries due to missiles. ${ }^{59,60,64} \mathrm{He}$ provided recommendations for the initial management of these injuries and categorized them according to their inciting mechanism. At 


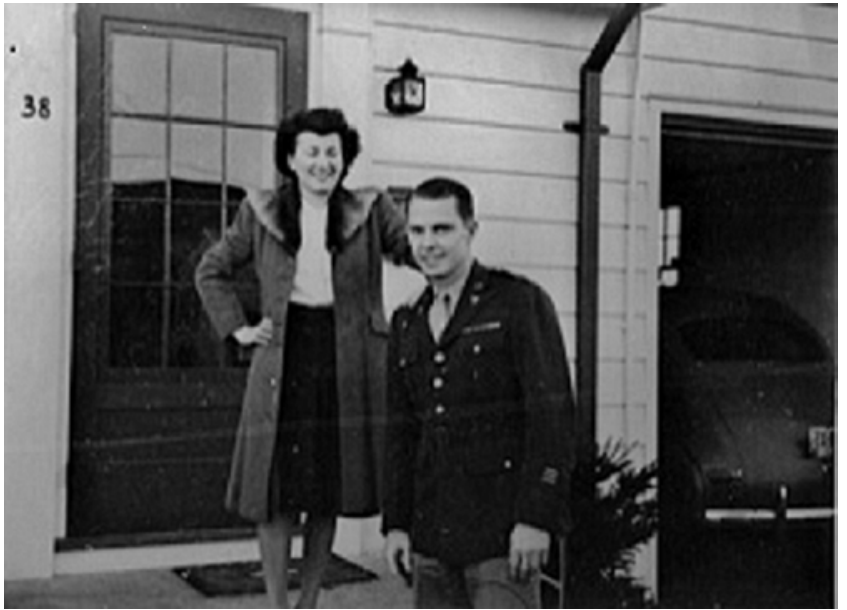

FIG. 2. Matson and Dottie, winter 1945. Copyright Barbara Matson. Published with permission.

the age of 33 , he finished his military service as a surgical leader and neurosurgical consultant to the First Army, earning a Bronze Star for his participation in the Battle of the Bulge (Donald Matson, personal communication) (Fig. 2)..$^{72}$

\section{Neurosurgery in Boston}

Matson returned to Boston in 1946 and joined Franc Ingraham at $\mathrm{BCH}$ as his research fellow and, subsequently, his partner. He participated in the reopening of the old Benedict Laboratory, which Ingraham converted into a neurosurgical lab in the Carnegie Building located across from the $\mathrm{BCH} .{ }^{54}$
Following the footsteps of his predecessors, Matson spent time away from Brigham and Children's to enhance his neurosurgical training. Cushing had spent a Wanderjahr abroad in 1900, visiting Emil Theodor Kocher (18411917) and Victor A. H. Horsley (1857-1916) in Europe. ${ }^{15}$ Cushing's disciple, Ingraham, spent time in Baltimore with Walter E. Dandy (1886-1946) and at Oxford with Sir Charles S. Sherrington (1857-1952) ${ }^{20}$ Matson spent 6 months at the Lahey Clinic working with Gilbert Horrax (1887-1957) and James L. Poppen (1903-1978). In 1947, he spent a year as a Brigham Traveling Fellow at Duke with Barnes Woodhall (1905-1985) and Guy L. Odom (1911-2001) and then returned to join Ingraham as a partner..$^{90}$

When Matson returned to Boston, he carried out fundamental neurosurgical and neurophysiological investigations, which contributed to the understanding of many pediatric pathologies. ${ }^{78}$ Over the next 20 years, Ingraham and Matson categorized the treatment of childhood conditions including hydrocephalus, brain and spinal tumors, brain abscess, intracranial hemorrhage, and congenital malformations (Fig. 3)..$^{55,56,63,69,92}$ According to Matson, about $40 \%$ of all neurosurgical admissions to $\mathrm{BCH}$ were patients with congenital malformations, a finding that emphasized the importance of "early recognition, definitive treatment, and faithful follow-up" for optimal treatment. ${ }^{63}$

With the aid of Mildred Codding, originally Cushing's artist, Ingraham and Matson published the first textbook in the world on pediatric neurosurgery, Neurosurgery of Infancy and Childhood, in 1954. ${ }^{17,43}$ Codding joined Ingraham and Matson in the operating room to closely observe the surgical procedures and record them in pen-andink drawings as preliminary sketches, based on her expe-

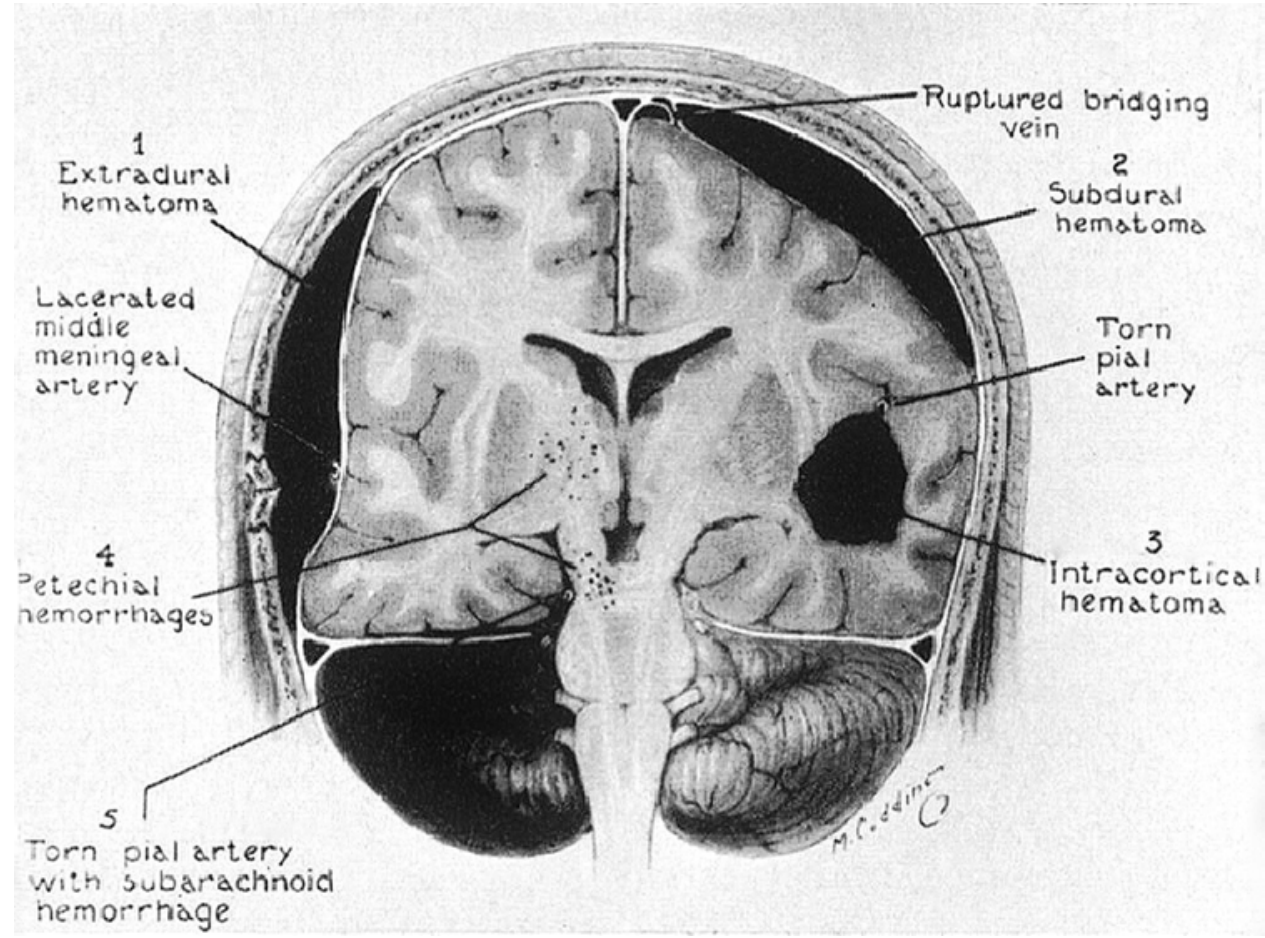

FIG. 3. Drawing by Mildred Codding, illustrating Matson's description of the types of intracranial hemorrhage. Reprinted from Matson DD: Craniocerebral trauma in childhood. Am J Surg 101:677-683, 1961. Copyright Elsevier. Published with permission. 
rience with Cushing. ${ }^{18,93}$ Before his death in 1969, Matson published a completely rewritten and more detailed second edition of the original work. ${ }^{61}$

Ingraham had suffered from serious illness throughout his life and was frequently incapacitated by bad bronchial asthma. He suffered a serious myocardial infarction in 1962 and retired in 1964. In the years before Ingraham's retirement, Matson had been doing most of the neurosurgical cases at the Brigham and Children's. Upon Ingraham's retirement, Matson became neurosurgeon-in-chief at both hospitals. Ingraham died of a second myocardial infarct at the age of 67 in the second year of his retirement, on December 4, $1965 .{ }^{20}$

Following Ingraham's death in 1965, an endowed chair was established in his name by HMS. ${ }^{54}$ There was a lengthy search to ensure that the first incumbent would be a worthy appointee, with a strong background in clinical neurosurgery and research. Although Matson was likely the reigning neurosurgeon in the country at the time, Harvard was slow in its deliberations. It took 3 years before they named Matson the inaugural Franc D. Ingraham Professor of Neurological Surgery at HMS. Sadly, Matson learned of the appointment while he was hospitalized at the Brigham in 1968 with the illness that subsequently took his life the following year. ${ }^{60}$

\section{Contributions to Neurosurgery}

Matson's experiences near the front lines in World War II enabled him reorganize previous concepts about wartime penetrating cranial and spinal injuries that had been described by Cushing in World War I. ${ }^{59,60}$ These concepts, which are still being used, came to be known as Matson's Tenets. ${ }^{48}$ The tenets were categorized as follows: 1) immediate saving of life (hematoma evacuation, brainstem decompression); 2) prevention of infection; 3) preservation of neural function; and 4) restoration of anatomical structure. In his monograph, Matson detailed the mechanisms and types of cranial and spinal injuries, postoperative care, and the use of antibiotics. ${ }^{65}$ His experiences, which focused on improvement of surgical techniques and a better understanding of the mechanisms of cranial injuries, helped to reduce the mortality rate of traumatic brain injury from $60 \%$ in World War I to $14.5 \%$, in World War II. ${ }^{60,95}$

Matson made important contributions to the treatment of hydrocephalus. His work developed from his interest in the pathophysiology of CSF circulation and from his compassion for the young children who would lose brain function and die of the disorder. ${ }^{15,57}$ The work of Walter Dandy and Kenneth Blackfan (1883-1941) on the anatomy of CSF flow had already led to advances in understanding of the pathogenesis of hydrocephalus. ${ }^{23-27,47}$ The first successful shunt system, the ventriculocisternal shunt, was introduced in 1939 by Arne Torkildsen (1899-1968). ${ }^{98}$

Matson aimed to develop a shunt device to treat hydrocephalus based on Torkildsen's work..$^{98,99}$ Ingraham's work with neuropathologist Orville Bailey (1909-1998) (Fig. 4 ), on the body's immunological response to biocompatible materials, established the basis for the use of synthetic plastic in surgery. ${ }^{5,6,40-42}$ Ingraham and Bailey studied the hemostatic properties of fibrin foam and thrombin. ${ }^{5,6}$ Building on their work, Matson evaluated the use of plastic materials, specifically polyethylene, in neurosurgery, which led to the use of plastic tubing for shunt surgery. ${ }^{41,42}$

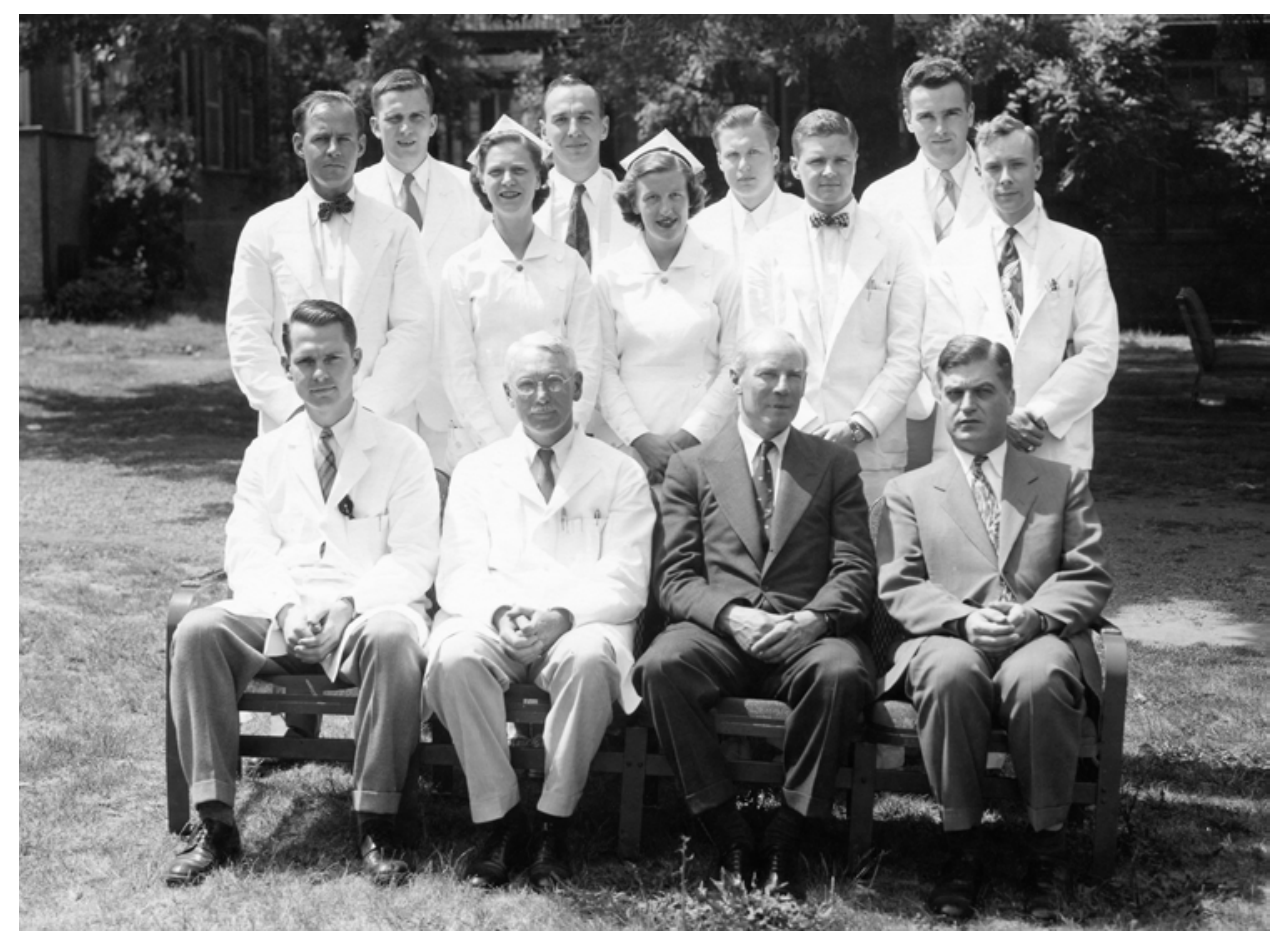

FIG. 4. Department of Neurosurgery at BCH in 1950. First row, left to right: Donald Matson, Franc Ingraham, Hugh Cairns (British Visiting Professor), Orville T. Bailey (neuropathologist). Second row, left to right: Edgar J. Bering Jr., Edith Battey, Ellen W. Parkis, Albert W. Farley Jr., Robert H. Shedd. Third row, left to right: John F. Prudden, Anthony F. Susen, J. S. Tola, Wilfrid T. Small. Copyright Boston Children's Hospital Archives, Boston, Massachusetts. Published with permission. 
Animal models simulating hydrocephalus were poor and ineffective, mostly due to the inadequate materials used for blocking the CSF pathways. . $2,25,27,33,34,40$ Dandy and Blackfan had previously reproduced hydrocephalus in dogs by introducing a piece of cotton into the aqueduct of Sylvius and the foramen of Monro. ${ }^{27}$ Controversy over the validity of Dandy's experiments arose because of the failure of some investigators to reproduce hydrocephalus with cotton. ${ }^{35}$

In 1947, Matson developed a model of progressive hydrocephalus in dogs using cellophane to block the CSF pathways. Previously, Irvin H. Page had reported on the inflammatory response of cellophane and scar tissue formation. ${ }^{77}$ Matson's cellophane model was considered to be the most accurate reproduction of hydrocephalus at the time.

Matson worked with Vannevar Bush (1890-1974) to develop a magnetic valve for the treatment of hydrocephalus..$^{45}$ Bush, an engineer at the Massachusetts Institute of Technology, served as director of the Office of Scientific Research and Development under Franklin Roosevelt during World War II. ${ }^{8}$ His wartime efforts transformed the American research enterprise and helped provide the US and Allied troops with powerful weapons and effective medical therapies. ${ }^{102}$

Early ventricular shunting was fraught with failure. Multiple sites were explored for CSF diversion, with limited success. In 1925, Heile developed a ureterodural anastomosis that entailed unilateral nephrectomy. ${ }^{38}$ In 1948, Matson modified Heile's procedure and performed the first successful lumbar-ureteral shunt. In this procedure, CSF was diverted through a plastic tube from the lumbar spinal subarachnoid space into a ureter after removal of a kidney. ${ }^{62}$ The operation was first performed in 1948 on an 8-year-old girl with postmeningitic hydrocephalus that developed after a motor vehicle accident. Matson was such a master surgeon that he performed his own nephrectomies in these cases (Fig. 5). According to his friend and classmate Francis Moore, Matson considered himself a general surgeon who accidentally became a neurosurgeon. He cared for all surgical patients in the hospital and regularly joined general surgery rounds with constructive comments. 3,72

Following Torkildsen's Operation and Matson's Procedure, various types of shunt were developed to treat hydrocephalus. These included the ventriculoureterostomy shunt by Matson in 1951, the ventriculojugular shunt by Frank E. Nulsen (1916-1994) and Eugene B. Spitz (19192006) in 1951, the ventriculotranscallosal shunt by Guy Lazorthes (1910-2014) in 1953, the ventriculopleural shunt by Joseph Ransohoff (1915-2001) in 1954, and the ventriculoperitoneal shunt by Michael Scott (1906-1979) in $1955.53,66,75,81,87,89,97$

Matson continued searching for more effective therapies for hydrocephalus. ${ }^{83} \mathrm{He}$ worked closely with Edgar A. Bering (1917-1994), who began as a neurosurgical resident at Brigham and Children's in 1949 and remained in the department as Director of the Neurosurgical Laboratories until 1961 (Fig. 6). ${ }^{9-12,16}$

Matson was a visionary who attempted to place these novel treatments for hydrocephalus in perspective. He

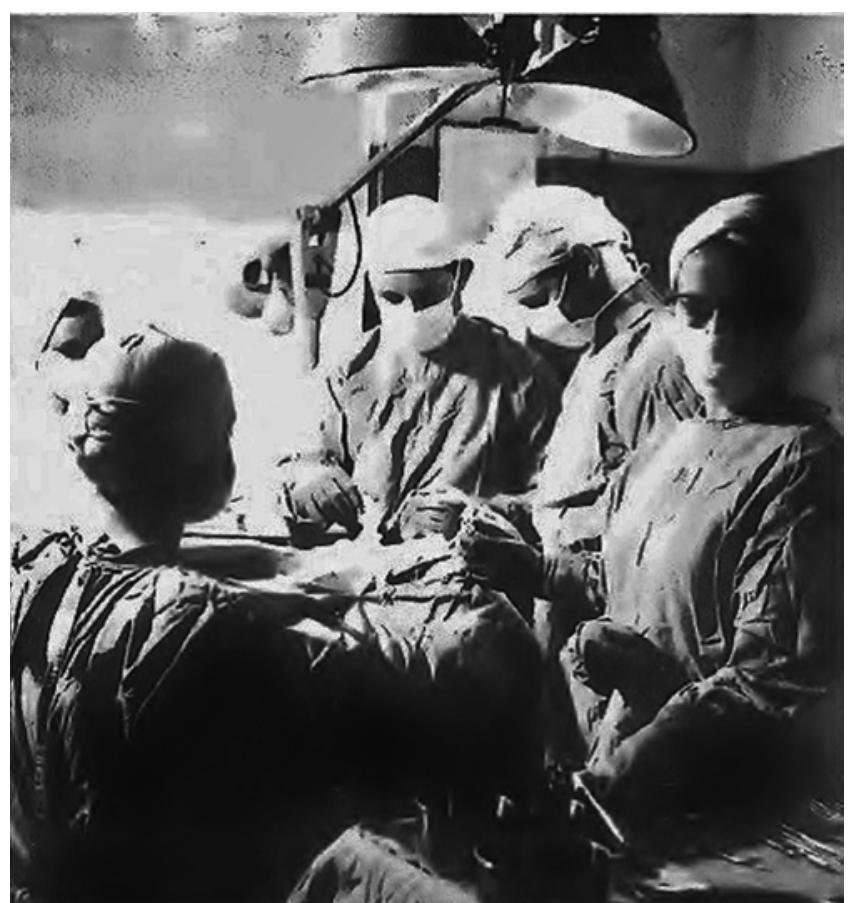

FIG. 5. Matson (second from right) in the operating room at $\mathrm{BCH}$. Copyright Boston Children's Hospital Archives, Boston, Massachusetts. Published with permission.

defended shunt surgery and its expenses, noting that "At a time when society is questioning the relevance of the highly specialized teaching hospital, using elaborate equipment and a large specialized staff for acute care, and is looking toward some sort of community goal, it is well to remember that at the center of the teaching hospital there are people who actually treat and cure major diseases that cannot be treated or even approached anywhere else in the world." 72

Another pioneering effort by Matson and his colleagues was the introduction of cortisone as an adjunct for surgery of pituitary tumors and craniopharyngiomas, foreshadowing its general use for the treatment of cerebral swelling. In 1952, Matson described the use of cortisone and ACTH to correct endocrinopathy in patients undergoing surgery for craniopharyngioma. ${ }^{46} \mathrm{He}$ believed that endocrine compromise from the expansive lesion was present in almost all patients, and better postoperative recovery was achieved whenever replacement therapy was used. He emphasized the need for complete excision at the initial surgery, followed by regular endocrine and neurological evaluation (Fig. 7). ${ }^{67,68}$ Remarkably, Matson carried out his complex craniopharyngioma resections in the era before introduction of the operating microscope.

Matson's interest in neuroendocrine disorders was not limited to surgery for craniopharyngioma. In 1959, he published a report in the New England Journal of Medicine about hypophysectomy in the palliative treatment of advanced breast cancer. ${ }^{50}$ Matson believed that the palliative procedure changed the progression of the disease favorably and demonstrated a 5-month increase in overall survival.

Like Cushing, Matson and his mentor Ingraham estab- 


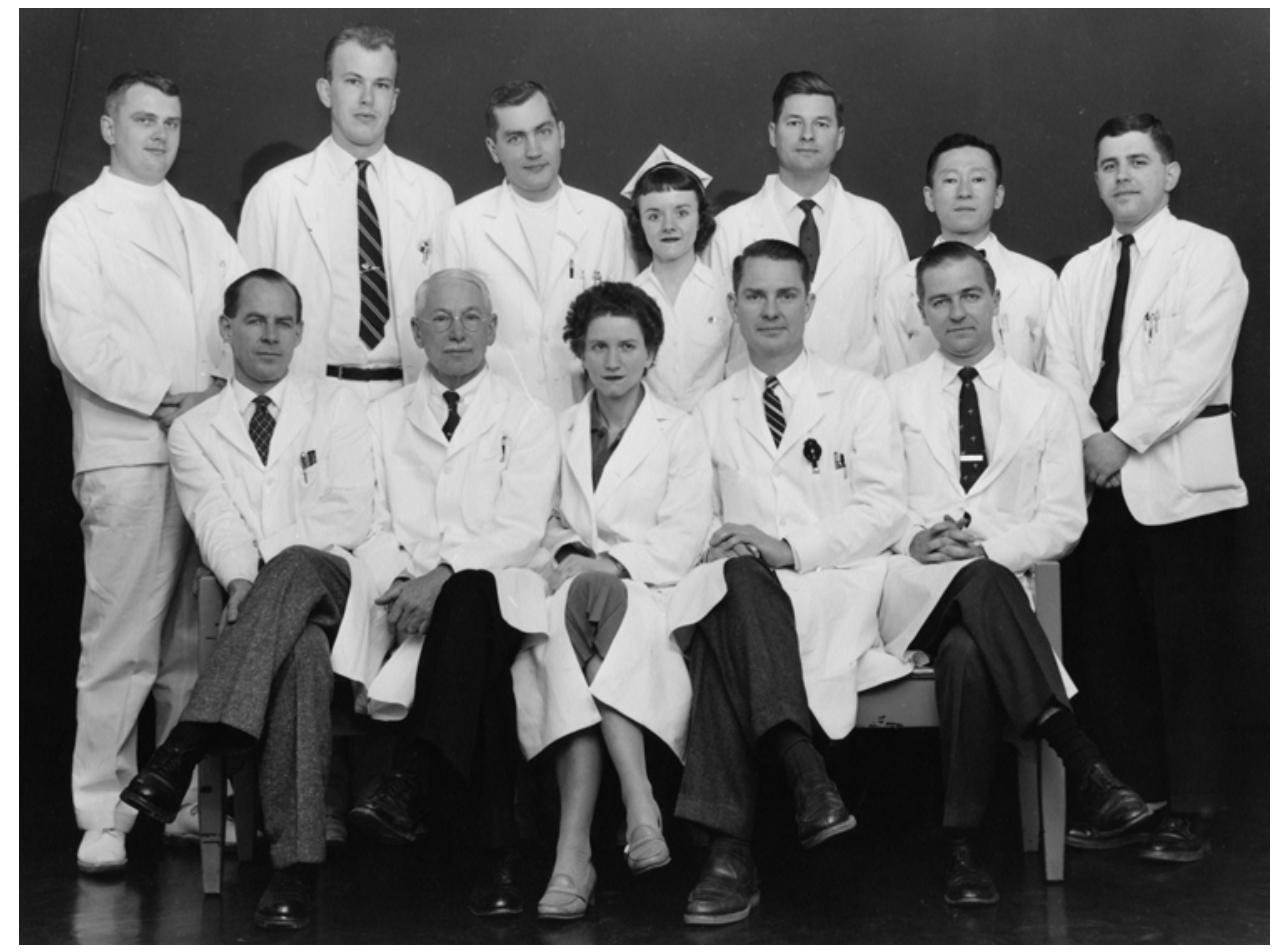

FIG. 6. Department of Neurosurgery at BCH in 1958. Front row, left to right: Edgar Bering, Franc Ingraham, Sabina Strich (British neuropathologist), Donald Matson, John Shillito. Back row, left to right: Lon Curtis, Lucius Hill, Robert Schick, Lois Farrell, Werner Isler, Shuro Nishimura, Ernest Mathews. Copyright Boston Children's Hospital Archives, Boston, Massachusetts. Published with permission.

lished a major neurosurgical training program and were able to attract talented recruits from around the world. ${ }^{100}$ The department hosted frequent visiting professors, including Sir Hugh W. B. Cairns (1896-1952), Nuffield Professor of Surgery at Oxford and Ingraham's close friend and colleague (Fig. 4). ${ }^{13}$ Matson and Ingraham trained almost 2 dozen residents, as well as many individuals who came for shorter periods to learn pediatric neurosurgery. ${ }^{90}$ Bruce Hendrick (1924-2001) arrived from Canada in 1952 for a 2-year fellowship and returned home to become director of pediatric neurosurgery at the Hospital for Sick Children in Toronto (Fig. 8). ${ }^{49}$ Other residents trained by Ingraham and Matson who went on to careers in pediatric neurosurgery include Robert L. McLaurin, John Shillito, Larry K. Page, and Alan D. Rosenthal. ${ }^{54}$

Matson had a powerful ability to bring science to the bedside. He commented that "Pediatric neurosurgery is work well rewarded by the innocent faith of the patients, by their uncanny resilience and ability to get well, by their parents' understanding and gratitude, and by the great variety of conditions which can be corrected (Fig. 9)." ${ }^{18}$

\section{Interdisciplinary Contributions}

Matson emphasized the importance of multidisciplinary collaboration to optimize the treatment and outcome of surgical patients. Some of his efforts contributed to postoperative endocrine management after tumor resection, the use of ultrasonic devices to detect intracranial pathology, and the development of plastic valves in the heart. ${ }^{16,17,94}$
Matson's lumbar-ureteral shunt procedure, which entailed the removal of a kidney, contributed to two Nobel Prizes: one for renal transplantation and another for the development of the polio vaccine. Some of the kidneys Matson removed were given to Joseph E. Murray (1919-2012) for transplantation. In 1954, Murray and his colleagues performed the world's first successful renal homotransplantation at PBBH, and 36 years later, in 1990, he shared the Nobel Prize in Physiology or Medicine with Edward Donnall Thomas (1920-2012) for their work on organ and cell transplantation. ${ }^{7,14,38,71,73}$

Other kidneys removed by Matson were sent to John F. Enders (1897-1985), a virologist at BCH, who used them as a medium on which to grow the poliovirus. ${ }^{85}$ For his work culturing the poliovirus, Enders was awarded the Nobel Prize in $1954 .^{28,72,74}$ It is somewhat remarkable that it was not until 1956, a full 2 years after he received the Nobel Prize, that Enders was promoted to the rank of professor at HMS.

\section{National Leadership}

Matson had an active role in national neurosurgical leadership. He served as secretary and subsequently chairman of the American Board of Neurological Surgery (ABNS). His pioneering work on the evaluating of his resident's performance set the basis for the current ABNS primary examination. ${ }^{2,72,78}$

Following the footsteps of Ingraham, Matson served on the editorial board of the Journal of Neurosurgery. ${ }^{90}$ He was chosen as the honored guest and opening speaker 


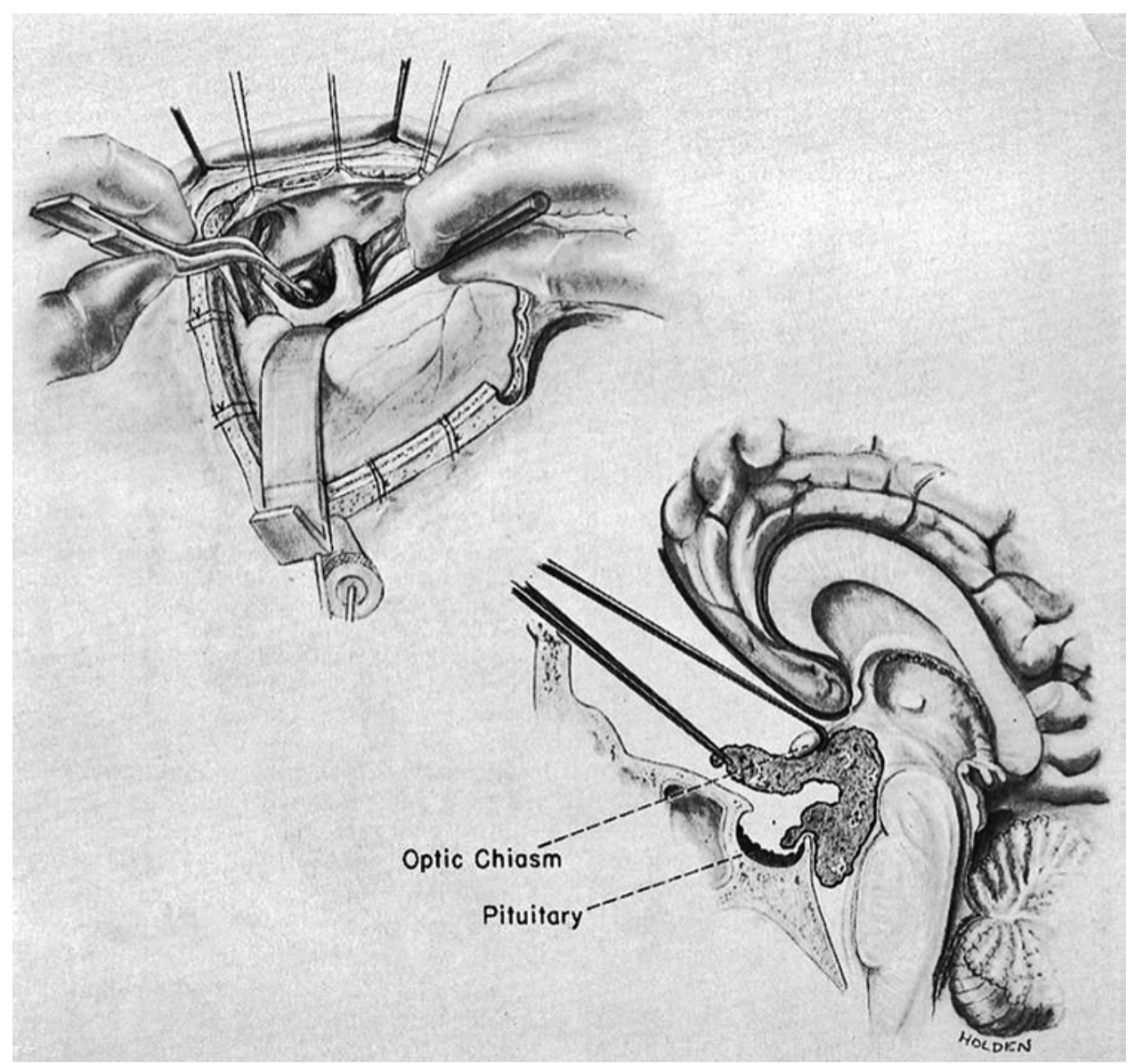

FIG. 7. Matson's approach to a craniopharyngioma. Reprinted from Matson DD, Crigler JF Jr: Management of craniopharyngioma in childhood. J Neurosurg 30:377-390, 1969.

at the first European Congress of Pediatric Neurosurgery held in Vienna, in 1967.78

In 1968, Matson was elected President of the American Association of Neurological Surgeons (AANS), founded in 1931 as the Harvey Cushing Society. ${ }^{2,91}$ He was also member of the American Surgical Association, the American College of Surgeons, the Halsted Society, the Society of University Surgeons, the New England Surgical Society, and the Scandinavian Neurosurgical Society (Fig. 10). ${ }^{3}$

\section{Family and Personal Life}

Matson was a brilliant man but also had a lighter side. In medical school, he participated in talent shows, which included the Aesculapian Show, at the Aesculapian Club, the oldest club at HMS (Harvard Medical School Aesculapian Club: Records of the Aesculapian Club, 1977-2007, http:// beta.worldcat.org/archivegrid/collection/data/808080920). In one of the performances, Matson played the role of John Rock, the obstetrician and gynecologist he had worked with in previous years. As those were the early days of the "rhythm method" of birth control, Matson sang the number, "Rock, Rhythm, Romance, and Remorse."72,90

In World War II, Matson was assigned to New York City for special officer training. During an officer's dance at the Roosevelt Hotel, he met an engaging psychiatric social worker, Dorothy Everett, his future wife. In 1943 they married, with Eben Alexander serving as best man..$^{72}$ After the war, Matson returned to Boston and joined Ingraham as his partner. The two men were close personal friends and Matson became godfather to Alice, Ingraham's daughter. ${ }^{20}$

Evenings at the Matson's home were described as warm and engaging. Matson and Dottie frequently invited the residents and their wives or girlfriends over to their home for meals and gatherings. During the informal sessions, Dottie had an uncanny way of dressing down Matson and making him seem more human, especially to those who worked daily with him. ${ }^{90}$

Matson and Dottie traveled throughout the world, combining vacations with attendance at international neurosurgical meetings. They spent extended periods in Scandinavia, England, and Australia, which allowed them to cultivate numerous warm and lasting friendships (Fig. 11).,4

Matson and Dottie had four children: two sons, Donald and James, and two daughters, Barbara and Martha. Matson was a devoted husband and father who managed to find time to drive his kids to school every day (Barbara Matson, personal communication). The family frequently traveled to Maine to spend time at their summer house. Matson enjoyed weekends with his family and on weekdays, while his family remained in Maine, he returned to Boston to care for his patients and fulfill his hospital obligations. ${ }^{80}$ 


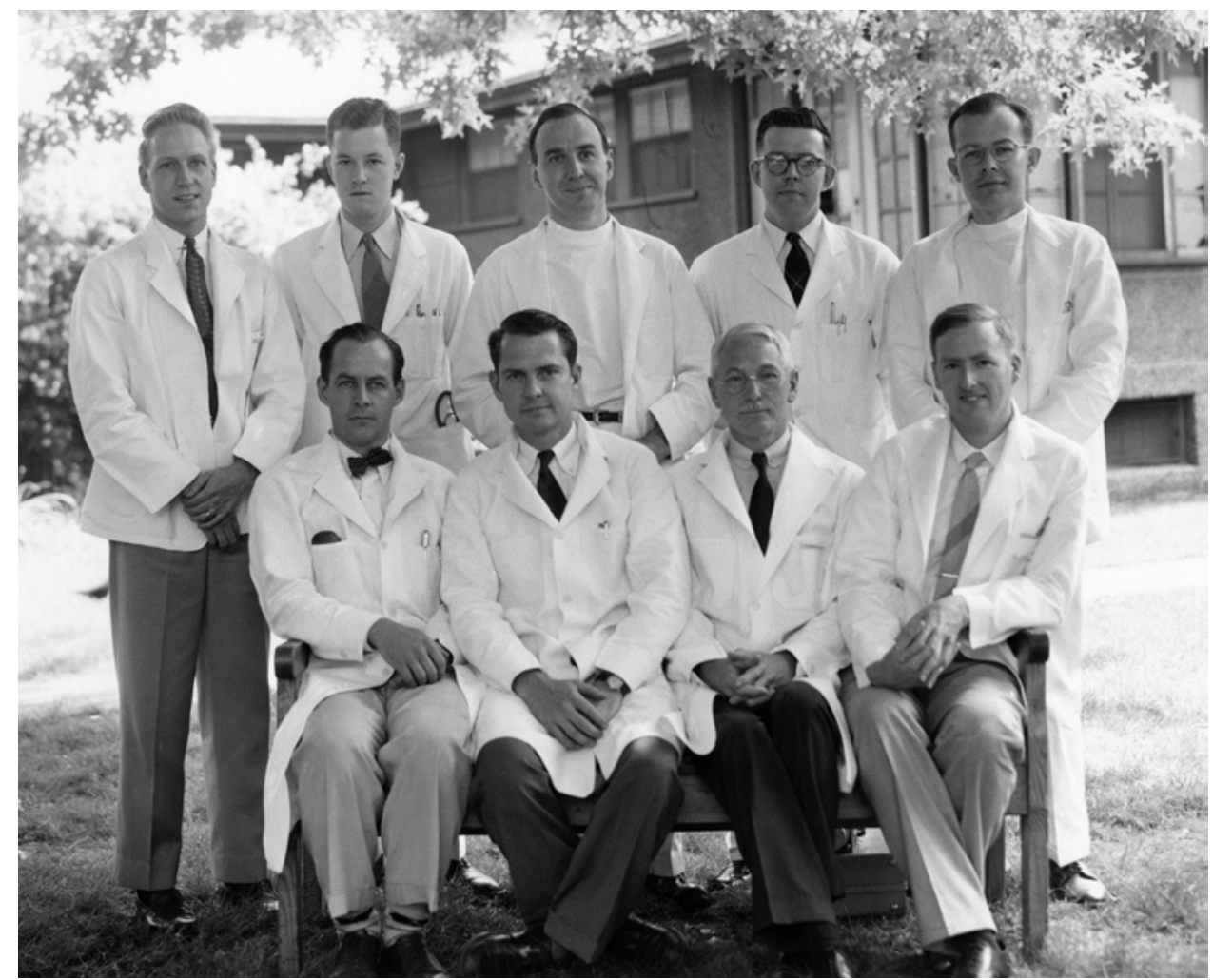

FIG. 8. Department of Neurosurgery at BCH in 1953. Front row, left to right: Edgar Bering, Donald Matson, Franc Ingraham, Peter Schurr. Back row, left to right: Robert L. McLaurin, Peter Teel, Anthony Susen, Bruce Hendrick, Lewis Brown. Copyright Boston Children's Hospital Archives, Boston, Massachusetts. Published with permission.

Dottie felt that Matson would have been happy to learn how his children fared in life, "I think he would have been proud and pleased at how all of them have managed their lives, even though there is not a neurosurgeon among them." 3 Matson is survived by his four grown children: Martha (Mardi), a retired hospital administrator; Donald, a union organizer and teacher; James (Jed), an electronic

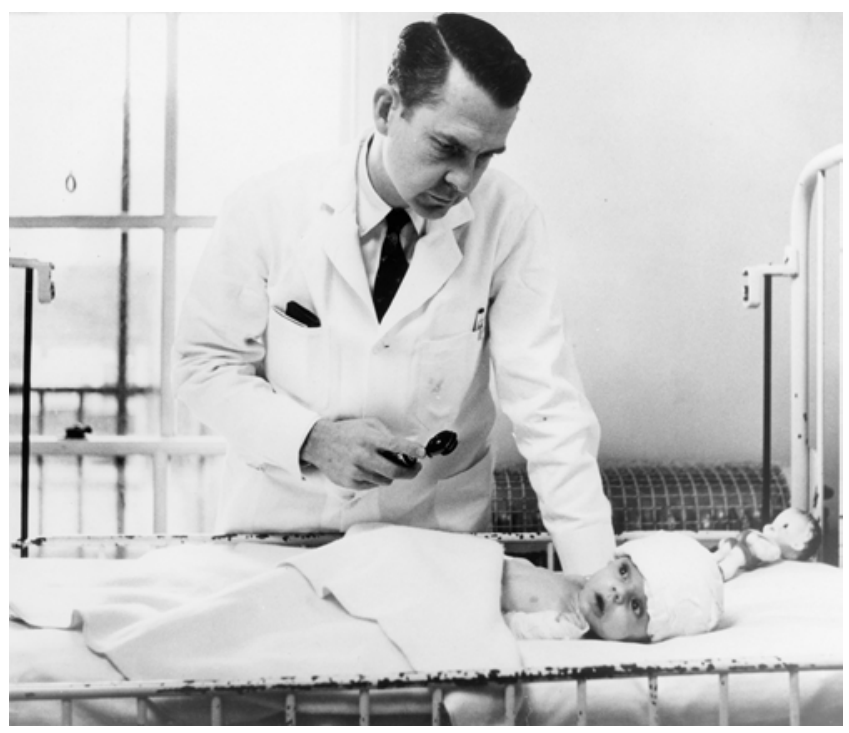

FIG. 9. Matson at the bedside. Copyright Boston Children's Hospital Archives, Boston, Massachusetts. Published with permission. engineer; and Barbara, an editor and writer (Barbara Matson, personal communication).

\section{Illness and Death}

In May of 1968, Matson was afflicted with an illness that incapacitated him for the latter half of that year. Early

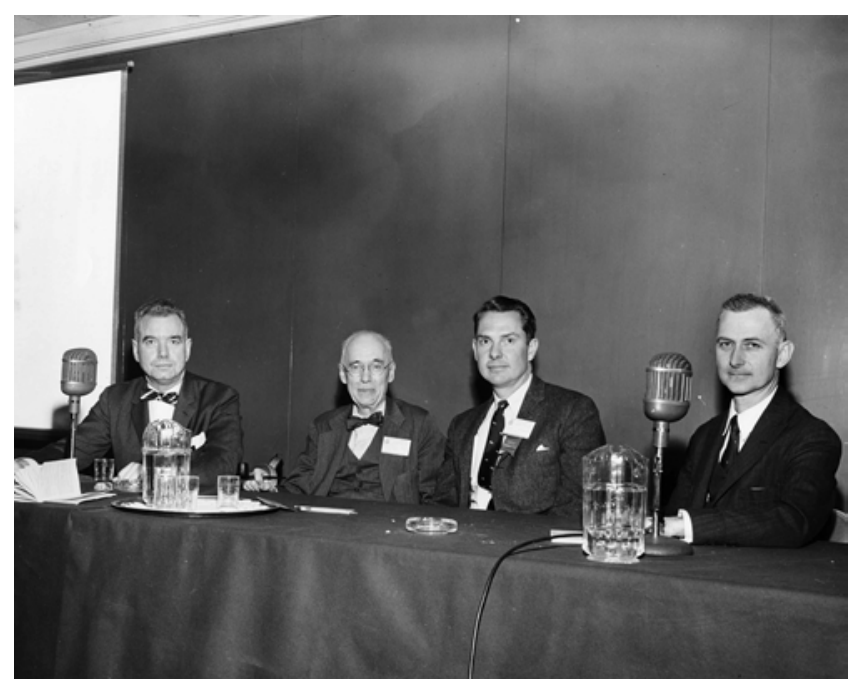

FIG. 10. College of Surgeons Sectional Meeting, 1960. Left to right: Donald Munro, H. Thomas Ballantine, Donald D. Matson, William H. Sweet. Copyright Boston Children's Hospital Archives, Boston, Massachusetts. Published with permission. 


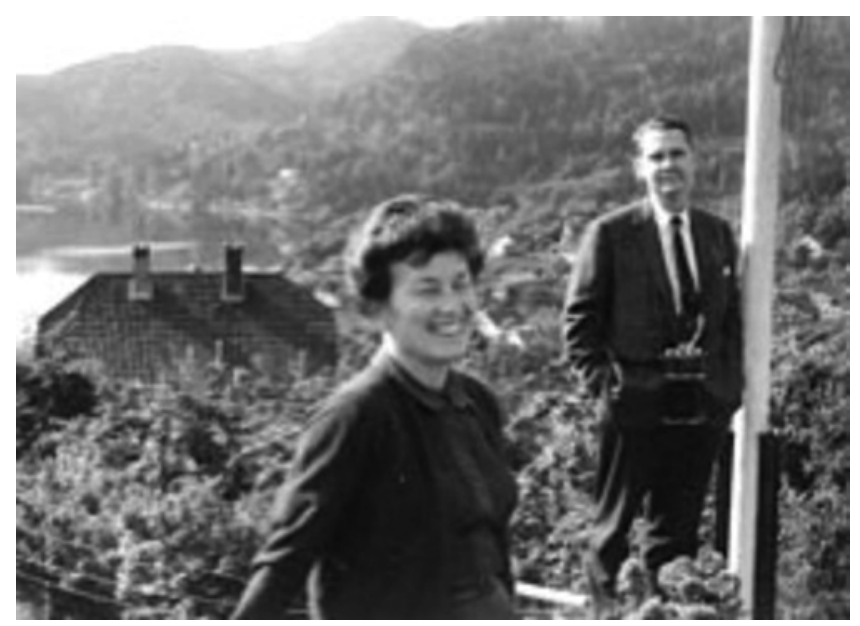

FIG. 11. Matson and Dottie in Denmark. Copyright Barbara Matson. Published with permission.

signs of the disease manifested while he was still active. Francis Moore visited Matson in the operating room one day and remembered Matson's greeting: "Good morning, I am sorry, I can't turn my head. It makes me a little dizzy. Maybe I am coming down with something." 72 Later that year, Matson was elected president of the Harvey Cushing Society. ${ }^{20}$ As he walked to the podium, he stumbled. One of his friends made fun of him, saying Matson probably had a little too much to drink early in the day (from an interview with Dr. John Shillito Jr., in the Boston Children's Hospital Oral History Archives, 1993).

Matson's symptoms began approximately 6 months prior to his first hospitalization at $\mathrm{PBBH}$. Initially he presented with abnormal sleep patterns, with early morning insomnia and interrupted night sleep, following by daytime sleep attacks with hallucinations and myoclonic twitching of the extremities. One month later, he presented with paresthesias of the toes, which he sensed as an electric current that began in the left great toe and spread to the other toes. A purpuric nonpruritic papular rash on the feet and legs followed. Matson's paresthesias progressed to the lower extremities. He developed hypersensitivity to noise and light and his wife observed a startle response on wakening. Before his first hospitalization, he had peripheral neuropathy of the lower extremities, loss of vibration sense, rotatory nystagmus, and ataxic gait. ${ }^{88}$

During the initial hospitalization, Matson carried out many of his duties from his hospital room. ${ }^{18}$ For the centennial commemoration of Harvey Cushing, he was able to publish a selection of Cushing's works, entitled Harvey Cushing: Selected Papers on Neurosurgery. ${ }^{21}$ Matson arranged for a plaque to be placed at the site of Cushing's birthplace at the beginning of the AANS meeting, and labored hard to arrange for the issuing of a stamp in honor of Cushing. ${ }^{4}$ Years later, in 1988, the stamp was printed by the US Postal Service. ${ }^{76}$ Matson also participated actively in the centennial commemorative issue of the Journal of Neurosurgery that appeared in April 1969. His last public appearance was at his daughter Mardi's wedding in the chapel of Boston Children's Hospital in December 1968. ${ }^{4}$

As his illness progressed, Matson developed loss of voice and progressive gait ataxia. He was readmitted to $\mathrm{PBBH}$ after 5 weeks for what was to be his final hospitalization. He had characteristics of Cushing syndrome due to the therapeutic course of prednisone and was moderately obtunded. ${ }^{88}$ The faculty at PBBH put him through many clinical studies and skin biopsies in search of a diagnosis. John Shillito, Matson's colleague, noted, "The ataxia progressed. We put the poor man through a PEG (pneumoencephalogram) as our then best diagnostic study, hoping to find something correctable. I remember well his terror at the time of position changes to accomplish that unpleasant study!"39 Matson often discussed the mysterious nature of his progressive disorder and its hopeless course. ${ }^{72} \mathrm{He}$ realized that he would probably never be able to operate again and often spoke of becoming a dean..$^{90}$

Throughout his illness, Matson was cared for by $\mathrm{H}$. Richard Tyler, neurologist-in-chief at PBBH. The working diagnosis, based on skin lesions and the acute and later chronic vasculitis, was Köhlmeier-Degos syndrome, a rare vasculopathy affecting small vessels in the skin, gastrointestinal tract, ocular, and central nervous systems. ${ }^{36,88}$ At one point there was an effort to transfer him to the Veterans Hospital for further care. Matson's physicians and colleagues became increasingly upset and contacted Joseph E. Levine, the famous film producer, who was a philanthropic supporter of PBBH. He was grateful to the Department of Neurosurgery, especially to Matson, who had previously operated on his wife Rosalie Harrison. Levine threatened to stop his financial support of PBBH if Matson were to be transferred elsewhere. The threat worked and Matson remained at PBBH (Francis Rockett, personal communication).

During the final months of his life, Matson became bedridden, lost the ability to speak and hear, and developed multiple cranial nerve palsies. Days prior to his death, he could no longer recognize his wife or physicians. After a long illness that lasted almost 2 years, he died at the age of 55, on Saturday May 10, 1969, at PBBH. His death followed the anniversary meeting of the AANS by only few short weeks. ${ }^{3}$ His memory is honored every year by the Matson Lectureship in Neurosurgery at HMS. ${ }^{100}$

Months after Matson's death, Gustave Dammin (19111991), chief pathologist at PBBH, consulted Daniel Carleton Gajdusek (1923-2008), an American physician and head of the laboratories for virus and neurological research at the National Institutes of Health. ${ }^{30,52,91,101}$ Gajdusek was an expert in disorders including scrapie in sheep and kuru in cannibalistic tribes of the South Pacific. At the time of Matson's autopsy, specimens of his brain and other organs were removed and frozen. Gajdusek inoculated Matson's brain tissue into several chimpanzees and squirrel monkeys. The animals became ill with a chronic progressive neurological disease that appeared clinically and histologically similar to Creutzfeldt-Jakob disease (CJD). ${ }^{30}$ Once the disease was found to be transmissible encephalopathy, an investigation confirmed that Matson had been consulted on a case of CJD 7 years earlier. At that time a myelogram had been performed, but Matson was not known to have participated in the procedure. The true cause of Matson's spongiform encephalopathy was never determined. ${ }^{88}$

Matson's illness had an atypical course. Usually in CJD, 
a rapidly progressive dementia develops and ends in death within a year of onset. In addition, myoclonus and periodic sharp wave EEG changes are usually found. Matson's dementia did not appear until late in the course of his illness, which lasted 18 months, and pronounced myoclonus and typical EEG patterns were also not observed.

In 1976 Gajdusek received the Nobel Prize for his work on CJD, the first human prion disease demonstrated to be infectious. ${ }^{32,51,70,82}$

\section{Conclusions}

Donald Darrow Matson, whose life was cut short by catastrophic illness, has been underrecognized for his role as a founding father of pediatric neurosurgery (Fig. 12). Through most of his adult life, Matson made seminal contributions to the field. In 1968, he was awarded the inaugural Franc D. Ingraham Professorship at HMS and was elected president of the AANS. Matson's death came at the young age of 55, following 2 years of progressive dementia from CJD. His life and legacy as one of the most outstanding neurosurgeons of his generation continue to inspire greatness in others in the field of pediatric neurosurgery (Fig. 13).

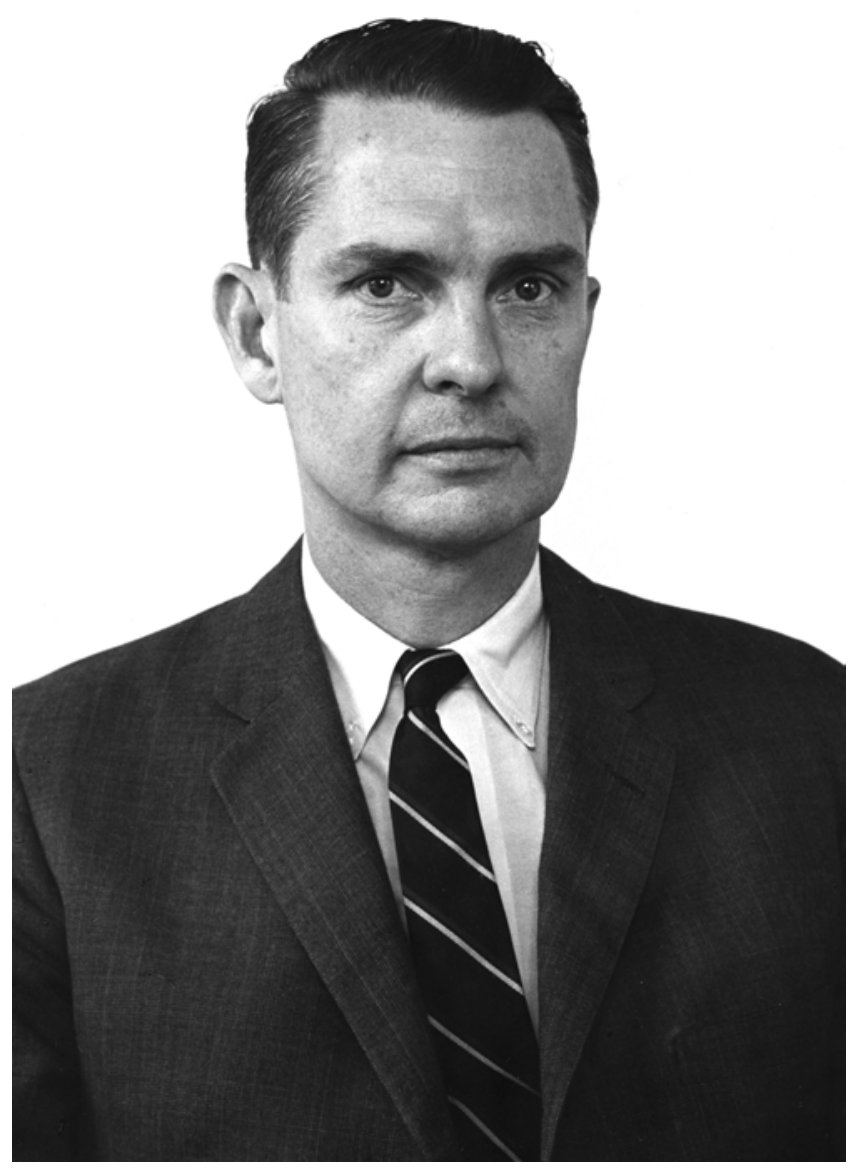

FIG. 12. Donald Matson, the first Franc D. Ingraham Professor of Neurosurgery at Harvard Medical School. Copyright Boston Children's Hospital Archives, Boston, Massachusetts. Published with permission.

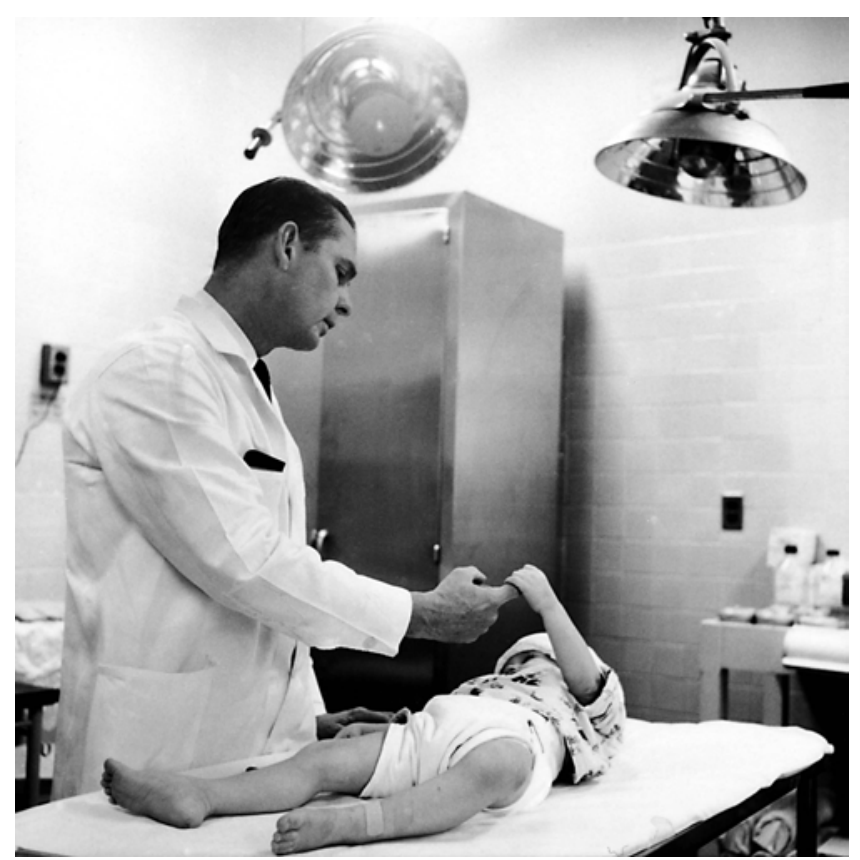

FIG. 13. Matson evaluating a child postoperatively in clinic. Copyright Boston Children's Hospital Archives, Boston, Massachusetts. Published with permission.

\section{Acknowledgments}

We thank Alina Morris, MLIS, Archivist at Boston Children's Hospital, for help with the illustrations. The following individuals provided valuable information that contributed to this report: Francis Rockett, MD; H. Richard Tyler, MD; Howard Eisenberg, MD; and Matson's children, Barbara and Donald.

\section{References}

1. Alexander E Jr: 3131C-World War II neurosurgery. J Neurosurg 93:901-904, 2000

2. Alexander E Jr: Donald Darrow Matson. N Engl J Med 281:327-328, 1969

3. Alexander E Jr: Donald Darrow Matson (1913-1969): a remembrance. Neurosurgery 24:289-292, 1989

4. Alexander E Jr: Donald Darrow Matson: November 28, 1913-May 10, 1969. J Neurosurg 31:249-252, 1969

5. Bailey OT, Ingraham FD: Chemical, clinical, and immunological studies on the products of human plasma fraction XXI. The use of fibrin foam as a hemostatic agent in neurosurgery: clinical and pathological studies. J Clin Invest 23:591-596, 1944

6. Bailey OT, Ingraham FD, Swenson O, Lowrey JJ, Bering EA Jr: Human fibrin foam with thrombin as a hemostatic agent in general surgery: experimental studies and clinical use. Surgery 18:347-369, 1945

7. Barry JM, Murray JE: The first human renal transplants. J Urol 176:888-890, 2006

8. Baru JS, Bloom DA, Muraszko K, Koop CE: John Holter's shunt. J Am Coll Surg 192:79-85, 2001

9. Bering EA Jr: Choroid plexus and arterial pulsation of cerebrospinal fluid; demonstration of the choroid plexuses as a cerebrospinal fluid pump. AMA Arch Neurol Psychiatry 73:165-172, 1955

10. Bering EA Jr: Studies on the role of the choroid plexus in tracer exchanges between blood and cerebrospinal fluid. J Neurosurg 12:385-392, 1955

11. Bering EA Jr: Water exchange in the brain and cerebrospi- 
nal fluid; studies on the intraventricular instillation of deuterium (heavy water). J Neurosurg 11:234-242, 1954

12. Bering EA Jr, Matson DD: A technic for prevention of severe hypothermia during surgery on infants. Ann Surg 137:407-409, 1953

13. Black PM: Harvey Cushing at the Peter Bent Brigham Hospital. Neurosurgery 45:990-1001, 1999

14. Brennan MF: Francis D. Moore, MD 1913-2001. Ann Surg 235:600-601, 2002

15. Canale DJL, Longo LD: Harvey Cushing and pediatric neurosurgery. Neurosurgery 27:602-611, 1990

16. Children's Hospital: The 1960 Annual Report of the Children's Hospital Medical Center. Boston: Children's Hospital, 1960

17. Children's Hospital: The $\mathbf{1 9 6 6}$ Annual Report of the Children's Hospital Medical Center. Boston: Children's Hospital, 1966, pp 74-76

18. Children's Hospital: The Children's Hospital Medical Center 100th Anniversary Annual Report, 1969. Boston: Children's Hospital, 1970, Vol 1, pp 64-68

19. Cohen AR: Boston children's hospital and the origin of pediatric neurosurgery. Childs Nerv Syst 30:1621-1624, 2014

20. Cohen AR, Vogel TW, Lidov HG: The lost art of localization: Franc Ingraham's legacy in pediatric neurosurgery. $\mathbf{J}$ Neurosurg Pediatr 12:642-654, 2013

21. Cushing H: Harvey Cushing: Selected Papers on Neurosurgery. New Haven: Yale University Press, 1969,

22. Cushing H, Sladen FJ: Obstructive hydrocephalus following cerebrospinal meningitis, with intraventricular injection of antimeningitis serum (Flexner). J Exp Med 10:548-556, 1908

23. Dandy WE: Extirpation of the choroid plexus of the lateral ventricles in communicating hydrocephalus. Ann Surg 68:569-579, 1918

24. Dandy WE: Idiopathic hydrocephalus. J Nerv Ment Dis 60:287-288, 1924 (Abstract)

25. Dandy WE: An operative procedure for hydrocephalus. Bull Johns Hopkins Hosp 33:189-190, 1922

26. Dandy WE: The operative treatment of communicating hydrocephalus. Ann Surg 108: 194-202, 1938

27. Dandy EW, Blackfan DK: The cerebrospinal fluid and hydrocephalus. J Nerv Ment Dis 42:776-777, 1915 (Abstract)

28. Enders JF, Weller TH, Robbins FC: Cultivation of the Lansing strain of poliomyelitis virus in cultures of various human embryonic tissues. Science 109:85-87, 1949

29. Fleming B: The Deep Springs College Cowboy Lunch. Antioch Rev 69:899, 2011

30. Gajdusek DC, Gibbs CJ Jr: Survival of Creutzfeldt-Jakobdisease virus in formol-fixed brain tissue. N Engl J Med 294:553, 1976 (Letter)

31. Goodyear D: The searchers. The New Yorker 82:62, 2006

32. Goudsmit J: Obituary: Daniel Carleton Gajdusek (19232008). Nature 457:394, 2009

33. Griffith JQ Jr, Fry WE, McGuinness A: Experimental and clinical studies in hydrocephalus: with especial reference to the occurrence of papilledema: with especial reference to the occurrence of papilledema. Am J Ophthalmol 23:245251,1940

34. Griffith JQ, Fry WE, Roberts E: Studies of criteria for classification of arterial hypertension: VII. Increased intracranial pressure and papilledema. Am Heart J 21:94-97, 1941

35. Guleke N: Uber die Entstehung des Hydrocephalus internus. Arch. klin. Chir. 162:533-550, 1930

36. Güven FO, Bozdağ KE, Ermete M, Karaman A: Degos' disease. Int J Dermatol 39:361-362, 2000

37. Hays SB, Coates JJB, Spurling RG, Woodhall B, McFetridge EM (eds): Surgery in World War II.
Neurosurgery. Washington DC: Office of the Surgeon General, 1958, Vol 1, pp 3-38

38. Hume DM, Merril JP, Miller BF, Thorn GW: Experiences with renal homotransplantation in the human: report of nine cases. J Clin Invest 34:327-382, 1955

39. Humphreys RP: The modernization of pediatric neurosurgery. The Donald D. Matson Lecture 2003. Childs Nerv Syst 20:18-22, 2004

40. Ingraham FD, Alexander E Jr, Matson DD: Experimental hydrocephalus. J Neurosurg 42:164-176, 1947

41. Ingraham FD, Alexander E Jr, Matson DD: Polyethylene, a new synthetic plastic for use in surgery; experimental applications in neurosurgery. J Am Med Assoc 135:82-87, 1947

42. Ingraham FD, Alexander E Jr, Matson DD: Synthetic plastic materials in surgery. N Engl J Med 236:402-407, 1947

43. Ingraham FD, Matson DD: Neurosurgery of Infancy and Childhood. Springfield, IL: Charles C Thomas, 1954

44. Ingraham FD, Matson DD: Subdural hematoma in infancy. J Pediatr 24:1-37, 1944

45. Ingraham FD, Matson DD, Alexander PE, Woods PR: Studies in the treatment of experimental hydrocephalus. J Neuropathol Exp Neurol 7:123-143, 1948

46. Ingraham FD, Matson DD, McLaurin, RL: Cortisone and ACTH as an adjunct to the surgery of craniopharyngiomas. N Engl J Med 246:568-571, 1952

47. Jackson IJ: A review of the surgical treatment of internal hydrocephalus. J Pediatr 38:251-258, 1951

48. Jallo J, Loftus CM: Neurotrauma and Critical Care of the Brain. New York: Thieme, 2011

49. Jea A, Al-Otibi M, Rutka JT, Drake JM, Dirks PB, Kulkarni AV, et al: The history of neurosurgery at the Hospital for Sick Children in Toronto. Neurosurgery 61:612-624, 2007

50. Jessiman AG, Matson DD, Moore FD: Hypophysectomy in the treatment of breast cancer. N Engl J Med 261:11991207,1959

51. Kurian GT: The Nobel Scientists: a Biographical Encyclopedia. Amherst NY: Prometheus Books, 2002

52. Lambert B: Gustave Dammin, pathologist, 80; authority on organ transplants (obituary). New York Times. October 13, 1991 (http://www.nytimes.com/1991/10/13/nyregion/ gustave-dammin-pathologist-80-authority-on-organtransplants.html) [Accessed June 12, 2015]

53. Lazorthes G, Anduze-Acher H, Campan L, Espagno J: [Transcallous ventriculocisternostomy; four year's experience; 50 surgical cases.] Neurochirurgie 3:59-64, 1957 (Fr)

54. Lohani S, Cohen AR: Franc D. Ingraham and the genesis of pediatric neurosurgery. J Neurosurg Pediatr 11:727-733, 2013

55. Matson DD: Book reviews: Eye symptoms in brain tumors. JAMA 180:349, 1961

56. Matson DD: Craniocerebral trauma in childhood. Am J Surg 101:677-683, 1961

57. Matson DD: Current treatment of infantile hydrocephalus. $\mathbf{N}$ Engl J Med 255:933-936, 1956

58. Matson DD: Lung abscess. N Engl J Med 222:15-21, 1940

59. Matson DD: The management of acute compound battleincurred injuries of the spinal cord, in Hays SB, Coates JB Jr, Spurling RG, et al (eds): Surgery in World War II. Neurosurgery. Washington DC: Office of the Surgeon General, 1960, Vol 2, p 731

60. Matson DD: The management of acute craniocerebral injuries due to missiles, in Hays SB, Coates JB Jr, Spurling RG, et al (eds): Surgery in World War II. Neurosurgery. Washington DC: Office of the Surgeon General, 1958, Vol I, p 479

61. Matson DD: Neurosurgery of Infancy and Childhood, ed 2. Springfield, IL: Charles C Thomas, 1969

62. Matson DD: A new operation for the treatment of commu- 
nicating hydrocephalus; report of a case secondary to generalized meningitis. J Neurosurg 6:238-247, 1949

63. Matson DD: Surgical treatment of birth defects involving the central nervous system. J Chronic Dis 10:131-138, 1959

64. Matson DD: The Treatment of Acute Compound Injuries of the Spinal Cord Due to Missiles. Springfield, IL: Charles C Thomas, 1948, Vol 23

65. Matson DD: The treatment of acute craniocerebral injuries due to missiles, in American Lectures Series 22. Springfield, IL: Charles C Thomas, 1948

66. Matson DD: Ventriculo-ureterostomy. J Neurosurg 8:398404, 1951

67. Matson DD, Crigler JF Jr: Management of craniopharyngioma in childhood. J Neurosurg 30:377-390, 1969

68. Matson DD, Crigler JF Jr: Radical treatment of craniopharyngioma. Ann Surg 152:699-704, 1960

69. Matson DD, Salam M: Brain abscess in congenital heart disease. Pediatrics 27:772-789, 1961

70. McNeil DG Jr: D. Carleton Gajdusek, who won Nobel for work on brain disease, is dead at 85 . New York Times. December 15, 2008; A33

71. Merril JP, Murray JE, Harrison JH, Guild WR: Successful homotransplantation of the human kidney between identical twins. J Am Med Assoc 160:270-282, 1956

72. Moore FD: As we knew him. Harv Med Alumni Bull 53:21-27, 1978

73. Murray JEH, Harrison JH: Surgical management of fifty patients with kidney transplants including eighteen pairs of twins. Am J Surg 105:205-218, 1963

74. Norrby E, Prusiner SB: Polio and Nobel prizes: looking back 50 years. Ann Neurol 61:385-395, 2007

75. Nulsen FE, Spitz EB: Treatment of hydrocephalus by direct shunt from ventricle to jugular vain. Surg Forum 1951:399-403, 1951

76. Ojemann RG: The tradition of Harvey Cushing commemorated by a stamp in the Great American stamp series. The 1987 AANS (American Association of Neurological Surgeons) presidential address. J Neurosurg 67:631-642, 1987

77. Page IH: A method for producing persistent hypertension by cellophane. Science 89:273-274, 1939

78. Page LK: History of pediatric neurosurgery in the United States and Canada. Childs Nerv Syst 7:53-55, 1991

79. Pincus G, Garcia CR, Rock J, Paniagua M, Pendleton A, Laraque F, et al: Effectiveness of an oral contraceptive. Science 130:81-83, 1959

80. Randolph J: Judson Randolph, MD, in Newman K (ed): American Academy of Pediatrics Pediatric History Center Oral History Project. Elk Grove, IL: American Academy of Pediatrics, 2007

81. Ransohoff J, Marini G, Shulman K: [The ventriculo-pleural shunt.] Minerva Neurochir 12:68-70, 1963 (Ital)

82. Richmond C: Carleton Gajdusek. BMJ 338:b15, 2009

83. Robertson JT, Shick RW, Morgan F, Matson DD: Accurate placement of ventriculo-atrial shunt for hydrocephalus under electrocardiographic control. J Neurosurg 18:255-257, 1961

84. Rock J, Bartlett MK, Matson DD: The incidence of anovulatory menstruation among patients of low fertility. Am J Obstet Gynecol 37:3, 1939

85. Rosen FS: Isolation of poliovirus - John Enders and the Nobel Prize. N Engl J Med 351:1481-1483, 2004

86. Ross FP: Master surgeon, teacher, soldier, and friend: Elliott
Carr Cutler, MD (1888-1947). Am J Surg 137:428-432, 1979

87. Scarff JE: Treatment of hydrocephalus: an historical and critical review of methods and results. J Neurol Neurosurg Psychiatry 26:1-26, 1963

88. Schoene WC, Masters CL, Gibbs CJ Jr, Gajdusek DC, Tyler HR, Moore FD, et al: Transmissible spongiform encephalopathy (Creutzfeldt-Jakob disease). Atypical clinical and pathological findings. Arch Neurol 38:473-477, 1981

89. Scott M, Wycis HT, Murtagh F, Reyes V: Observations on ventricular and lumbar subarachnoid peritoneal shunts in hydrocephalus in infants. J Neurosurg 12:165-175, 1955

90. Shillito J Jr: Donald Darrow Matson, 1913-1969. Surg Neurol 20:437-439, 1983

91. Shillito J Jr, Black PM: The Harvard Neurosurgical Service at the Children's Hospital Boston and Brigham \& Women's Hospital, 1912-2007. Neurosurgery 63:579-593, 2008

92. Shillito J Jr, Matson DD: Craniosynostosis: a review of 519 surgical patients. Pediatrics 41:829-853, 1968

93. Shillito J Jr, Rossitch E Jr: Mildred Codding: An interview with Cushing's medical artist. Surg Neurol 35:341-344, 1991

94. Spencer FC: Surgical treatment of valvular heart disease. V. Prosthetic replacement of the mitral valve. Am Heart J 76:576-580, 1968

95. Spurling RG: Neurosurgery (and the neurosurgeon) in World War II. J Am Med Assoc 135:473-476, 1947

96. Streible D: Johnny Weissmuller. American National Biography Online. (http://www .anb.org/articles/18/ 18-01851.html) [Accessed June 12, 2015]

97. Torkildsen A: Brain operation in cases of obstructive hydrocephalus. J Egypt Med Assoc 36:77-92, 1953

98. Torkildsen A: A new palliative operation in cases of inoperable occlusion of the sylvian aqueduct. Acta Psychiatr Scand 14:221, 1939

99. Torkildsen A: Ventriculocisternostomy: a Palliative Operation in Different Types of Non-Communicating Hydrocephalus. Oslo: Grundt Tanum, 1947

100. Tyler HR: Donald Matson, in Ashwal S (ed): The Founders of Child Neurology. San Francisco: Norman Publishing, 1990, pp 794-797

101. Wheeler HB, Carson JM, Dammin GL: Transplantation of tissue slices in mice. Ann N Y Acad Sci 129:11, 1966

102. Wiesner JB: Vannevar Bush, 1890-1974. Washington DC: National Academy of Sciences, 1979

103. Xydas S, Widmann WD, Hardy MA: William E. Ladd: Father of pediatric surgery. Curr Surg 60:47-50, 2003

\section{Author Contributions}

Conception and design: Cohen, Rehder. Acquisition of data: all authors. Analysis and interpretation of data: Cohen, Rehder. Drafting the article: all authors. Critically revising the article: all authors. Reviewed submitted version of manuscript: all authors. Administrative/technical/material support: Rehder. Study supervision: Cohen, Rehder.

\section{Correspondence}

Alan R. Cohen, Department of Neurosurgery, Boston Children's Hospital, 300 Longwood Ave., Boston, MA 02115. email: alan. cohen@childrens.harvard.edu. 